Article

\title{
Agroecological and Social Transformations for Coexistence with Semi-Aridity in Brazil
}

\author{
Aldrin M. Pérez-Marin ${ }^{1}{ }^{*}$, Paul Rogé ${ }^{2}$, Miguel A. Altieri ${ }^{2}$, Luis F. Ulloa Forero ${ }^{3}$, \\ Luciano Silveira ${ }^{4}$, Victor M. Oliveira ${ }^{3}$ and Barbara E. Domingues-Leiva 5 \\ 1 Instituto Nacional do Semiárido (INSA), Programa de Pós-Graduação em Ciência do Solo da Universidade \\ Federal da Paraíba, Av. Francisco Lopes de Almeida, s/n, Serrotão, Campina Grande, \\ Paraíba CEP 58429-970, Brazil \\ 2 Department of Environmental Science, Policy and Management (ESPM), University of California, \\ Berkeley, CA 94720, USA; proge@berkeley.edu (P.R.); agroeco3@berkeleydu (M.A.A.) \\ 3 Instituto Nacional do Semiárido (INSA), Project INSA-ASA, Av. Francisco Lopes de Almeida, s/n, Serrotão, \\ Campina Grande, Paraíba CEP 58429-970, Brazil; luisfelipeulloa@gmail.com (L.F.U.F.); \\ oliveiravmn@gmail.com (V.M.O.) \\ 4 Articulação do Semiarido Brasileiro (ASA), Assessoria a Projeto em Agricultura Alternativa (ASPTA), \\ Rua Nicarágua, 111, Espinheiro, Recife, Pernambuco CEP 52020-190, Brazil; luciano@aspta.org.br \\ 5 Laboratory of Agroecology, University of California, Berkeley, CA 94720, USA; b.dleiva@gmail.com \\ * Correspondence: aldrin.perez@insa.gov.br
}

Academic Editor: Vincenzo Torretta

Received: 24 March 2017; Accepted: 3 June 2017; Published: 8 June 2017

\begin{abstract}
This article explores whether a shift in development paradigm resulted in coexistence with semi-aridity for residents of the Semi-Arid region of Brazil (SAB). If so, which strategies contributed and which conditions facilitated it? We conducted a comparative analysis of the transformations that occurred in 10 territories of the SAB during two time periods: PI (1973-2001) when "development" policies almost exclusively aimed to "combat drought and its effects"; and PII (2002-2016) when a concept of coexistence with semi-aridity informed policy making. Our study from the 10 territories of the SAB show significant changes between PI and PII. On average, there was a substantial improvement in Access to Water Infrastructure $(+33 \% \Delta)$, Diversification of Production Systems (Animals $+36 \% \Delta$; Crops $+61 \% \Delta$ ), Management of Common Pool Resources $(+45 \% \Delta)$ ), Involvement in Spaces of Political Organizing $(+24 \% \Delta)$, and Access to Public Programs $(+29 \% \Delta)$. As such, "coexistence" went from concept to action as a consequence of structural, agroecological, social, and management transformations in combination with a strengthening of mechanisms for community reciprocity. These were characterized by (a) the creation of resource reserves for use during times of drought; (b) the efficient use of available natural resources; and (c) enhanced articulation between diverse actors.
\end{abstract}

Keywords: agroecology; social change; public policy; semi-arid regions; Brazil

\section{Introduction}

Drylands, with diverse levels of aridity, represent close to $40 \%$ of the continental landmass [1]. It is estimated that more than $42 \%$ of the world population inhabits these areas, accumulating life experiences connected to the particular climatic dynamics of these dryland regions [2-6]. Historically, the conceptualization of reality that has influenced the technical, economic, and social imaginary has built and institutionalized an image of problematic regions full of adversities [7]. Despite the opportunities in these regions, there exist few experiences where relationships have formed between the State and Society, where the population has had a voice and a say in decision making through 
partnership and collaboration for the design, execution, and control of public policy. In this context, the Brazilian experience presented here becomes relevant at the global level.

The drylands of Brazil are located in the Semi-Arid region of Brazil (SAB), with an extension exceeding $900,000 \mathrm{~km}^{2}$, distributed in 1135 municipalities, representing $11.5 \%$ of the national territory. This region encompasses greater than 24 million rural properties, of which one million possess less than 5 hectares [8]. The intensive use of land for agriculture, livestock, forestry, and mining is the principal vector for desertification in dryland systems. It is likely that the SAB will be negatively affected in terms of agricultural and animal productivity by increased temperatures, increased frequency and intensity of droughts, and by decreased availability of water resources that result from processes of desertification and climate change [9-12].

Due to its climatic characteristics, the SAB has historically been the target of government policies aimed at what would be its "development", guided almost exclusively to combat drought and its impacts, and to promote mega-projects of irrigated agriculture [13-15]. These governmental policies for the region were characterized by: (a) economic exploitation with an explicit element of occupation and control over local resources; (b) a fragmented and technical vision of the local problems and opportunities for overcoming drought and its consequences; and (c) the implementation of the two previously mentioned aspects in order to benefit the political and economic elites in the region [14].

This model of development was widely implemented in the 20th century, but found itself in a state of crisis because it ignored principles that became known as environmental, economic, societal, and cultural "sustainability". In other words, unsatisfactory indices of development persisted in the region, and the structural situation of poverty became accentuated, particularly during periods of prolonged drought.

The prevailing development paradigm was questioned by peasant farmers and their organizing bodies-syndicates, associations, churches, and non-profit organizations-who demanded permanent solutions to the root of the problems afflicting the SAB [14-16]. In 1993, during a severe drought that affected the region, hundreds of rural workers mobilized in various forms of protest, which resulted in the creation of the Northeast Forum (Foro Nordeste) $[15,16]$. By June of that year, the Northeast Forum submitted a collection of proposals to the President of the Republic at that time via the National Confederacy of Agricultural Workers (Confederação Nacional dos Trabalhadores da Agricultura, CONTAG) and various provincial federations of rural workers. These proposals culminated in a Federal Program of Governmental Actions for the Northeast (Programa Federal de Ações do Governo Federal para o Nordeste). The discussions of the Northeast Forum reached the level of the Brazilian States as Provincial Partnerships for the Brazilian Semi-Arid Region (Articulações Provinciais do Semiárido). Based on these accumulated experiences, the Partnership for the Brazilian Semi-Arid Region (Articulação do Semiárido Brasileiro, ASA-Brasil) was formed in 1999 during the 3rd Conference of the Parties to the United Nations Convention to Combat Desertification (UNCCD) held in Recife, Pernambuco. During this event, ASA-Brasil released its Declaration on the SAB (Declaracão do SAB), which was based on the concept of "coexistence with semi-aridity" (convivencia com o semi-aridez) [14]. This concept emphasized two pillars: (a) the conservation and sustainable use of natural and water resources, and (b) the dismantling of monopolies on land, water, and other means of production [15].

The election of Luis Ignacio Lula da Silva in 2002 expanded participation by new social and political actors that responded more fully, coherently, and in a locally contextualized manner to a concept of sustainable development for the SAB. This new framework of the SAB encouraged the recuperation and valorization of strategies for coexistence developed by the actual residents of the region. It was based on environmental sustainability in combination with a commitment to improve the quality of life for families through incentives for pertinent economic activities.

This innovative shift in perception remedied the mistakes of the past that attributed the problematic situation of the SAB to natural conditions, particularly climate. Instead, inhabitants of the region assumed responsibility within the scope of their capabilities. They recognized ecological limits. The idea coalesced that sustainable development of the SAB fundamentally depends on 
a change of mentality by abandoning the indiscriminate use of natural resources and transforming harmful practices [17]. In brief, it signaled a rupture with a paradigm of adversities and the embrace of a paradigm of possibilities.

The objective of this article is to examine whether there has in fact been a realization of the proposed coexistence with semi-aridity, and if so, establish which general conditions contributed to it. This was accomplished using a comparative analysis of the transformations that occurred in 10 territories of the SAB in two time periods, PI (1973-2001) and PII (2002-2016), as a result of the implementation of new governmental development policies based on the concept of "coexistence with semi-aridity" in the years 2002-2016. The variables and processes that we analyzed included: (a) Physical Capital; (b) Access to Water Infrastructure; (c) Diversity of Animal Production Systems; (d) Diversity of Crop Production Systems; (e) Participation in the Management of Common Pool Resources; (f) Involvement in Spaces of Political Organizing; and (g) Participation in the Creation of Public Policy.

\section{Materials and Methods}

This study occurred in the context of a participatory research project called Monitoring Resilient Agricultural Systems in the SAB (Monitoramento Sistemas Agrícolas Resilientes no SAB), designed and realized in 2012-2016 by a collaboration between the National Institute of the Semi-Arid Region (Instituto Nacional do Semiárido, INSA) and ASA-Brasil, which brings together more than 3000 non-profit organizations that serve approximately 2 million families (Figure 1).

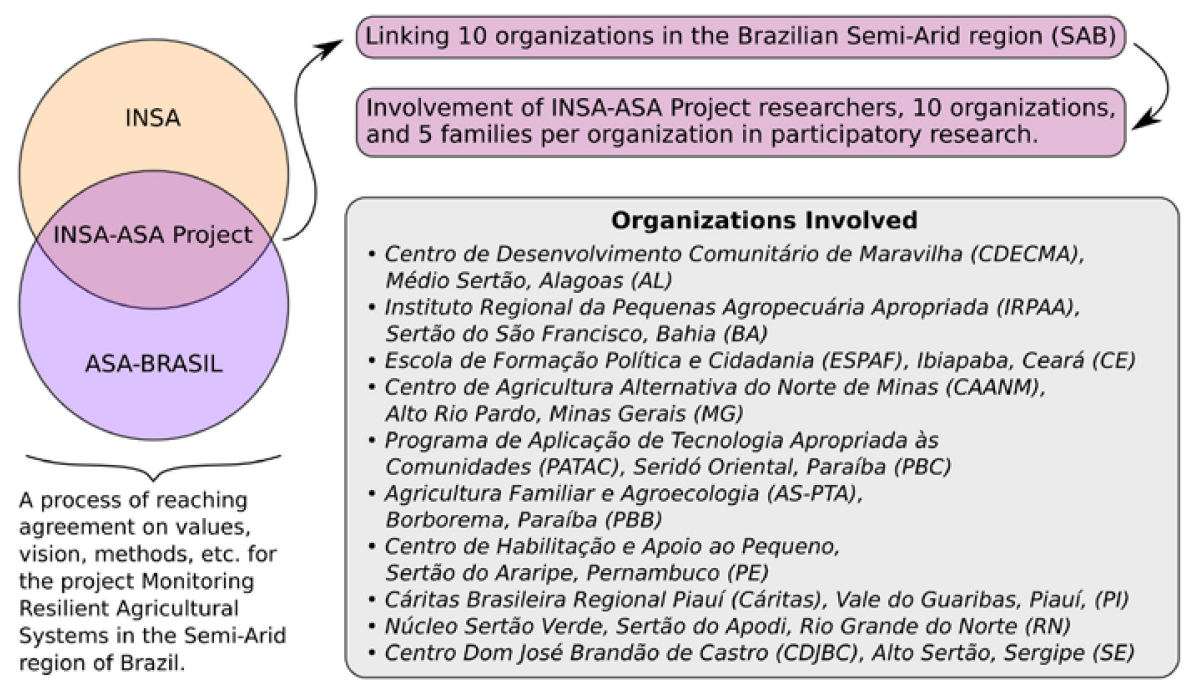

Figure 1. Process of articulation and participatory research developed by ASA-Brasil and INSA during the design, co-construction, and execution of the project Monitoring Resilient Agricultural Systems in the SAB (Monitoramento Sistemas Agrícolas Resilientes no SAB) referred to as either ASA-INSA or INSA-ASA.

To realize our field research, we initially identified, selected, and mobilized local institutions associated with ASA-Brasil that worked with sustainable agriculture and/or strategies of coexistence with semi-aridity in 10 territories within nine states of the SAB. Subsequently, the institutions in each territory indicated communities and families with whom they worked and who participated in the programs Training and Mobilization for Coexistence with the Semi-Arid Region: 1 Million Rural Cisterns (Formação e Mobilização para a Convivência com o Semi-Árido: 1 Milhão Cisternas Rurais) and One Earth and Two Bodies of Water (Uma Terra e Duas Águas). In total, 45 families participated during a period of three years (five families per state). Using semi-structured interviews, local researchers and 
supporting organizations carefully documented the characteristics and mechanisms associated with management strategies for coexistence with drought, as well as efforts to recover these strategies.

Our analysis of each system leveraged a version of a timeline methodology (linha do tempo) [18]. This methodological instrument helped identify macro-indicators and their associated indicators related to agroecosystems (Table 1) and territories (Table 2). These indicators reflect the perception and knowledge of participating families, who highlighted the relevance of the indicators for their co-existence with semi-aridity. The following steps were taken: (1) qualitative characterization and historic review of the agricultural systems in the territories that we studied; (2) visits to the properties, to observe and understand the systems on family farms; (3) identification of the elements significant to the quality of life for families; and (4) revision, provisioning, and socialization of the results through 100 local workshops with communities in the study territories and six regional workshops with representatives from six regions encompassing all the study territories between 2012 and 2016. In parallel, the timeline was complemented by a qualitative description of interactions between components within the families' agroecosystems using resource flow diagrams that provided a complete visualization of information regarding economic, technical, and social management of family production units. The flow diagrams and qualitative descriptions supported the analytical process, but are not the primary focus of this article.

Table 1. Macro-indicators and indicators associated with strategies for agroecosystem transformations aimed at coexistence with semi-aridity that were co-constructed during semi-structured interviews with families using a timeline methodology to track changes in the study territories between PI (1973-2001) and PII (2002-2016).

\begin{tabular}{|c|c|c|}
\hline Macro-Indicator & Indicator & Acronym \\
\hline \multirow{4}{*}{ Physical Capital (PC) } & Acquisition of Lands (by purchase) & $\mathrm{AL}$ \\
\hline & Acquisition of Habitation & $\mathrm{AH}$ \\
\hline & Production Infrastructure & PI \\
\hline & Acquisition of Equipment & $\mathrm{AE}$ \\
\hline \multirow{11}{*}{ Access to Water Infrastructure (AWI) } & Domestic Cisterns & DC \\
\hline & Production Cisterns & PC \\
\hline & Contour Ditches & $\mathrm{CD}$ \\
\hline & Watering Holes & WH \\
\hline & Large Reservoirs & LR \\
\hline & Subterranean Dams & SD \\
\hline & Stone-lined Reservoirs & SL \\
\hline & Cement-lined Wells & $\mathrm{CW}$ \\
\hline & Artesian Wells & AW \\
\hline & Micro-Reservoir & MR \\
\hline & Reuse of Water & RW \\
\hline \multirow{7}{*}{ Diversity of Animal Production Systems (DAPS) } & Production of Poultry & PP \\
\hline & Production of Cattle & PC \\
\hline & Production of Goats & PG \\
\hline & Production of Sheep & PSE \\
\hline & Production of Bees & PB \\
\hline & Production of Fish & PF \\
\hline & Production of Swine & PSW \\
\hline \multirow{8}{*}{ Diversity of Cropping Systems (DCS) } & Horticultural Crops & $\mathrm{HC}$ \\
\hline & Crop Associations (Roçados) & CA \\
\hline & Pastures and Grazing Areas & PGA \\
\hline & Reforestation and Tree Planting & RTP \\
\hline & Home Gardens & HG \\
\hline & Legal Reserve Areas & LRA \\
\hline & Shade-grown Coffee & SC \\
\hline & Forage Stocks & FS \\
\hline
\end{tabular}


Table 2. Macro-indicators and indicators associated with strategies for territorial governance aimed at coexistence with semi-aridity that were co-constructed during semi-structured interviews with families using a timeline methodology to track changes in the study territories between PI (1973-2001) and PII (2002-2016).

\begin{tabular}{|c|c|c|}
\hline Macro-Indicator & Indicator & Acronym \\
\hline \multirow{6}{*}{$\begin{array}{l}\text { Participation in the Management of } \\
\text { Common Pool Resources (PMCPR) }\end{array}$} & Family Seed Reserves & FSR \\
\hline & Community Seed Banks & CSB \\
\hline & Organization of Collective Labor & OCL \\
\hline & Participation in Associations & PA \\
\hline & Rotating Solidarity Funds & RSF \\
\hline & Fruit Processing & FP \\
\hline \multirow{5}{*}{$\begin{array}{c}\text { Involvement in Spaces of Political } \\
\text { Organizing (ISPO) }\end{array}$} & Participation in Cooperatives & ASC \\
\hline & Participation in Syndicates for Rural Workers & PSRW \\
\hline & Diverse Networks & $\mathrm{DN}$ \\
\hline & Participation in Trade Unions & PTU \\
\hline & Participation in Social Movements & PSM \\
\hline \multirow{7}{*}{ Access to Public Programs (APP) } & Farmers Markets & FM \\
\hline & Food Purchasing Program & FPP \\
\hline & National School Food Program (Programa Nacional da Alimentação Escolar) & NSFP \\
\hline & Program for Family Farms (Programa da Agricultura Familiar) & PFF \\
\hline & Bank of the Northeast (Banco do Nordeste) & $\mathrm{BNE}$ \\
\hline & Family Grants (Becas Familia) & FG \\
\hline & Income from Grants & IG \\
\hline
\end{tabular}

We analyzed the data from the timeline methodology using R [19]. The percentages presented in this study reflect the presence or absence of the indicators in both periods. The means for each period were compared using a $t$-test for paired data with $5 \%$ probability. In addition, the percentage of change between the time periods was calculated using the following equation:

$$
\% \Delta=\frac{P I I-P I}{P I} \times 100
$$

\section{Results}

There was a significant difference between the means of the indicators analyzed for PII (2002-2016) in comparison with PI (1973-2001) for the 10 territories of the SAB that we studied $\left(+39 \% \Delta, \mathrm{df}=479, p\right.$-value $\left.<2.2 \times 10^{-16}\right)$. This was a result of increased public policy reflecting coexistence with drought and the mobilization of inhabitants in processes facilitated by ASA-Brasil. In particular, these changes occurred as a result of the programs Coexistence with the Semi-Arid Region: 1 Million Rural Cisterns and One Earth and Two Bodies of Water that were implemented in cooperation with the Federal Government of Brazil. As such, Figure 2a,b illustrates a substantial improvement in macro-indicators when comparing the means of PI and PII. Figure $2 c$ shows specific increases in Physical Capital $(\mathrm{PC},+8 \% \Delta, \mathrm{df}=39, p$-value $=0.13)$, Access to Water Infrastructure $\left(\right.$ AWI $,+33 \% \Delta, \mathrm{df}=109, p$-value $\left.=4.1 \times 10^{-11}\right)$, Diversity of Animal Production Systems (DAPS, $+36 \% \Delta, \mathrm{df}=69, p$-value $\left.=1.2 \times 10^{-7}\right)$, Diversity of Cropping Systems $(\mathrm{DCS},+61 \% \Delta, \mathrm{df}=79$, $p$-value $<2.2 \times 10^{-16}$ ), Participation in the Management of Common Pool Resources (PMCPR, $+45 \% \Delta$, $\mathrm{df}=59, p$-value $\left.=6.6 \times 10^{-9}\right)$, Involvement in Spaces of Political Organizing $(\mathrm{ISPO},+24 \% \Delta, \mathrm{df}=49$, $p$-value $=0.001)$, and Access to Public Programs (APP, df $=69, p$-value $\left.<2.0 \times 10^{-6}\right)$. 

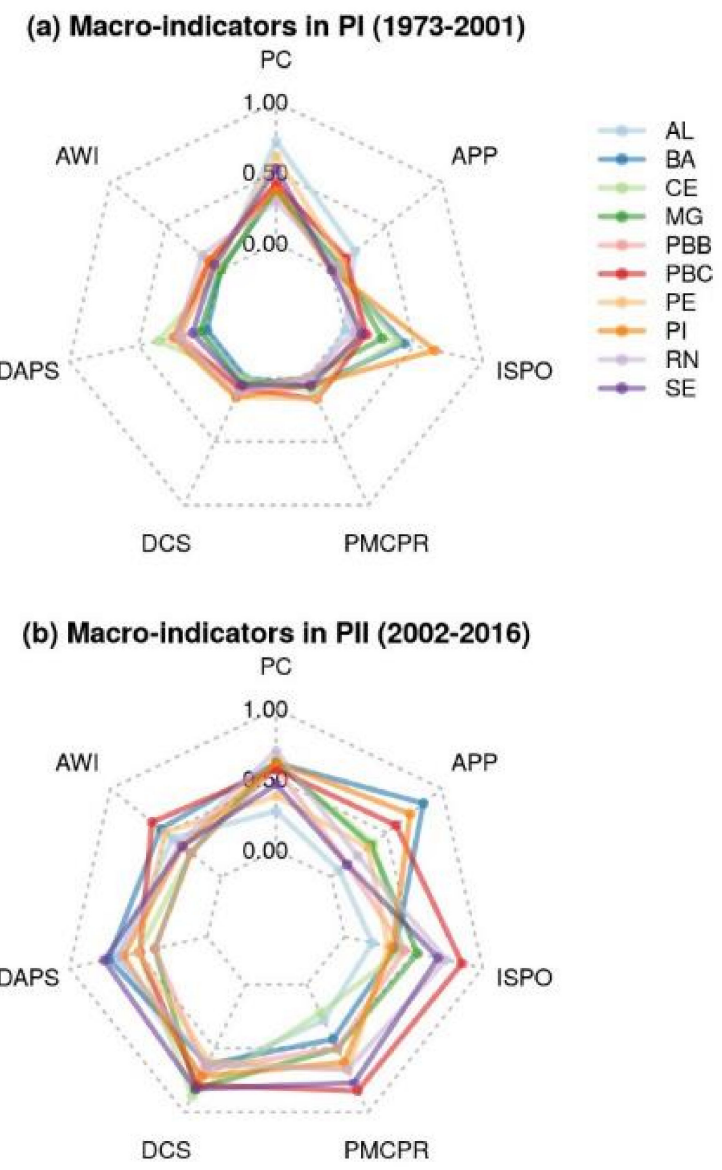

(c) Percent change for macro-indicators

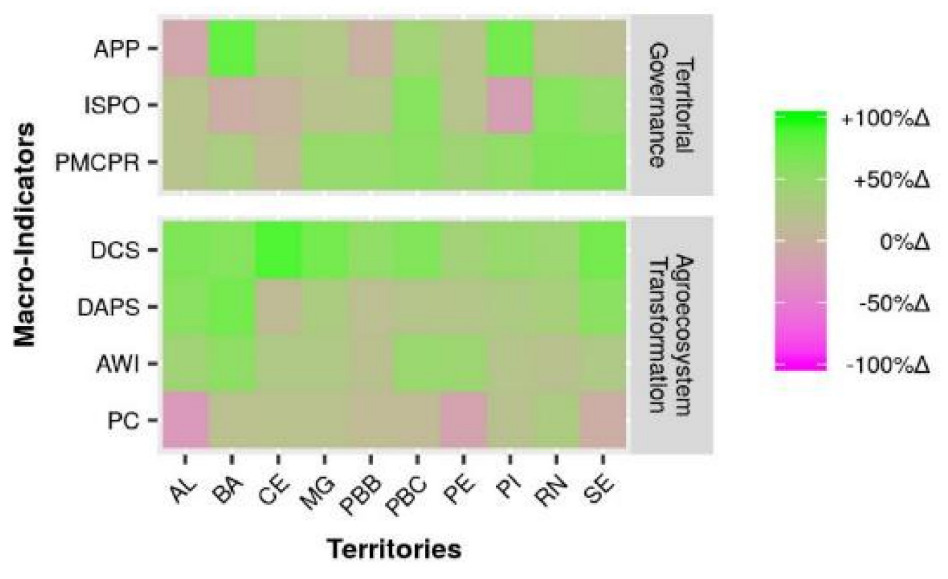

Figure 2. Mean scores for the macro-indicators from 10 territories of the Semi-Arid region of Brazil (SAB) in (a) PI (1973-2001) and (b) PII (2002-2016). Also displayed are (c) the percent change in the scores of the macro-indicators from PI to PII by territory, divided into the categories of Territorial Governance and Agroecosystem Transformation. The macro-indicators represented are: Physical Capital (PC), Access to Water Infrastructure (AWI), Diversity of Animal Production Systems (DAPS), Diversity of Cropping Systems (DCS), Participation in the Management of Common Pool Resources (PMCPR), Involvement in Spaces of Political Organizing (ISPO), and Access to Public Programs (APP). The territories displayed are: Médio Sertão-Alagoa (AL), Sertão San Francisco-Bahia (BA), Ibiapaba-Ceará (CE), Alto Rio Pardo-Minas Gerais (MG), Borborema-Paraíba (PPB), Carirí-Paraíba (PBC), Sertão do Araripe-Pernambuco (PE), Vale do Guaribas-Piauí (PI), Sertão do Apodi-Rio Grande do Norte (RN), and Alto Sertão-Sergipe (SE). 
In the case of Physical Capital (PC), the Acquisition of Lands (AL, $-11 \% \Delta)$ and Habitation $(\mathrm{AH},-14 \% \Delta)$ were slightly better in PI compared to PII (Figure 3). Nevertheless, PII exhibited better performance for the indicators of Infrastructure (PI, $+29 \% \Delta$ ) and the Acquisition of Equipment $(\mathrm{AE},+51 \% \Delta)$ because once families acquire lands and habitation, they tend to invest in improving their productive capacity. We point out that despite the relative advances in the purchase of land verified by this study, the SAB generally continues to have a high concentration of landholdings. According to the National Brazilian Institute for Geography and Statistics [20], approximately $60 \%$ of landholdings less than 10 ha occupy only $3 \%$ of arable lands, while the $2.3 \%$ of properties greater than 200 ha occupy $46 \%$ of arable lands in the region. As such, the SAB continues to have a large concentration of land ownership, as well as of water access.
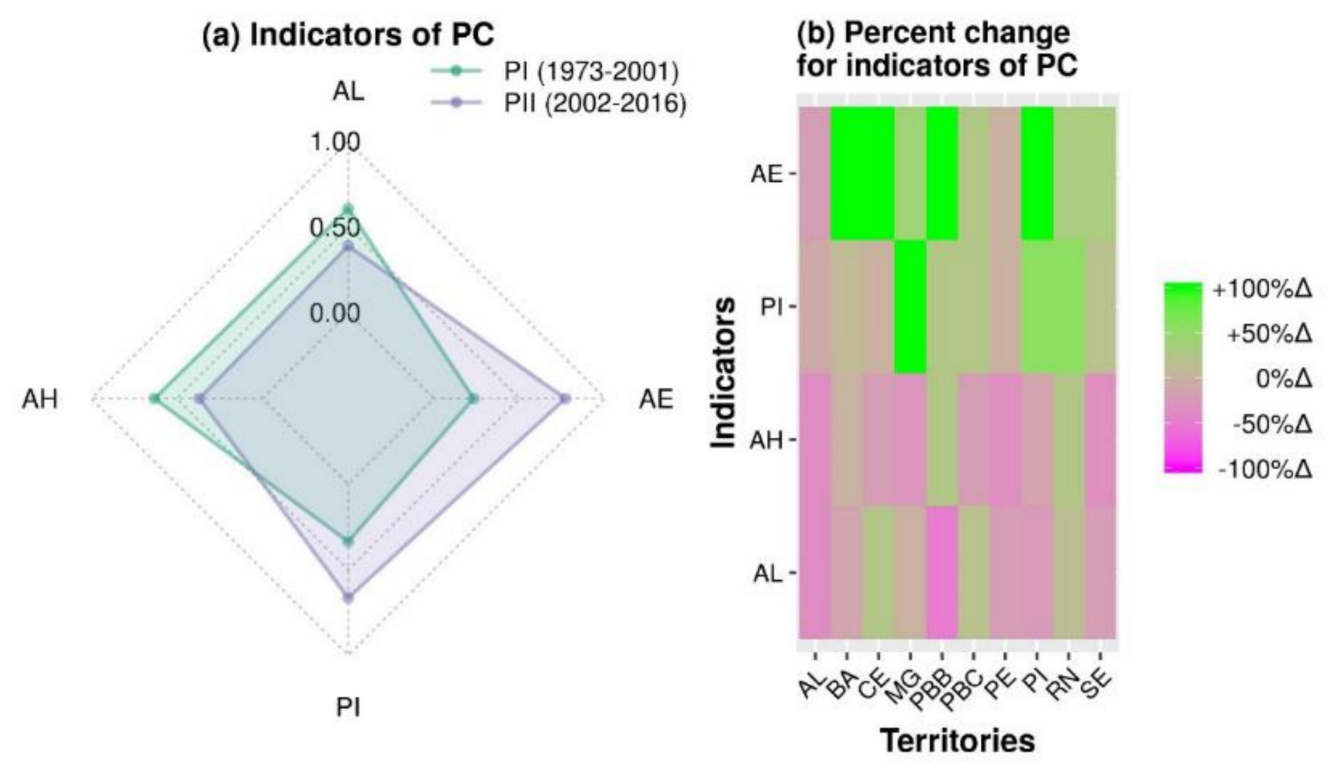

Figure 3. (a) Mean scores in PI (1973-2001) and PII (2002-2016) of the indicators comprising the macro-indicator Physical Capital (PC): Acquisition of Lands (AL), Acquisition of Habitation (AH), Production Infrastructure (PI), and Acquisition of Equipment (AE); (b) Percent change in these same indicators from PI to PII by territory: Médio Sertão-Alagoa (AL), Sertão San Francisco-Bahia (BA), Ibiapaba-Ceará (CE), Alto Rio Pardo-Minas Gerais (MG), Borborema-Paraíba (PPB), Carirí-Paraíba (PBC), Sertão do Araripe-Pernambuco (PE), Vale do Guaribas-Piauí (PI); Sertão do Apodi-Rio Grande do Norte (RN), and Alto Sertão-Sergipe (SE).

In the case of Access to Water Infrastructure (AWI, Figure 4), there was an improvement in the diverse technologies used to access and harvest water. This was most dramatically captured with respect to Domestic Cisterns $(\mathrm{DC},+58 \% \Delta)$ and access to Production Cisterns $(\mathrm{PC},+95 \% \Delta)$. There was also an increase in Micro-Reservoirs (MR, $+43 \% \Delta$ ), Stone-lined Reservoirs (SR, $+25 \% \Delta$ ), Cement-lined Wells $(\mathrm{CW},+45 \% \Delta)$, and Watering Holes $(\mathrm{WH},+53 \% \Delta)$. The forms of water infrastructure with the greatest presence in all the territories during PII were DC, PC, and WH.

Similar results from the indicators of water infrastructure were obtained for the indicators of agroecosystem diversification (Figures 5 and 6). There was an average increase of more than $42 \%$ for Diversity of Animal Production Systems (DAPS, Figure 5), notably due to small livestock such as Poultry $(\mathrm{PP},+62 \% \Delta)$, Swine (PSW, $+62 \% \Delta)$, Sheep (PSE, $+59 \% \Delta)$, Fish $(\mathrm{PF},+30 \% \Delta)$, and Bees $(\mathrm{PB},+25 \% \Delta)$. The mean increase for the diversification of cropping systems was greater than $63 \%$ (DCS, Figure 6), particularly due to Crop Associations known as roçados $(\mathrm{CA},+71 \% \Delta)$, to Pastures and Grazing Areas (PGA, $+61 \% \Delta$ ), to Reforestation and Tree Planting (RTP, $+74 \% \Delta$ ), to Home Gardens $(\mathrm{HG},+95 \% \Delta)$, and to Forage Stocking $(\mathrm{FS},+80 \% \Delta)$. 

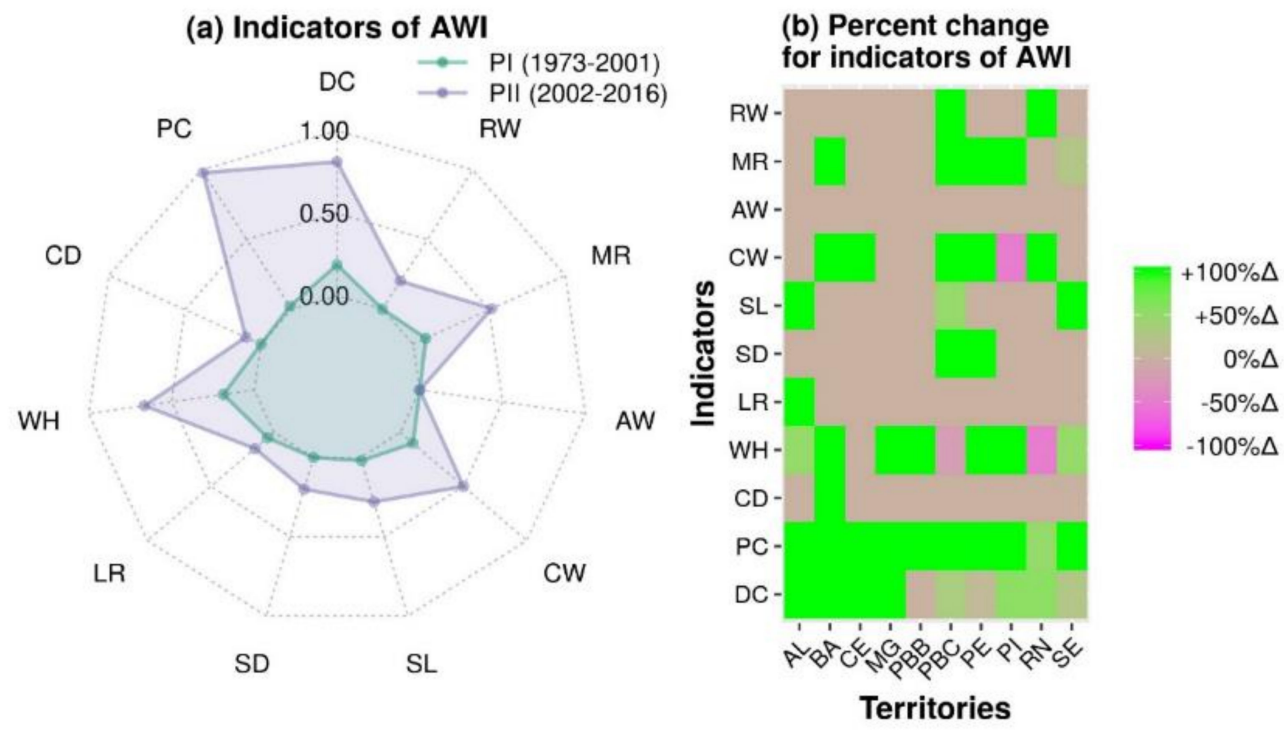

Figure 4. (a) Mean scores in PI (1973-2001) and PII (2002-2016) of the indicators comprising the macro-indicator Access to Water Infrastructure (AWI): Domestic Cisterns (DC), Production Cisterns (PC), Contour Ditches (CD), Watering Holes (WH), Large Reservoirs (LR), Subterranean Dams (SD), Stone-lined Reservoir (SL), Cement-lined Well (CW), Artesian Well (AW), Micro-Reservoir (MR), Reuse of Water (RW); (b) Percent change in these same indicators from PI to PII by territory: Médio Sertão-Alagoa (AL), Sertão San Francisco-Bahia (BA), Ibiapaba-Ceará (CE), Alto Rio Pardo-Minas Gerais (MG), Borborema-Paraíba (PPB), Carirí-Paraíba (PBC), Sertão do Araripe-Pernambuco (PE), Vale do Guaribas-Piauí (PI), Sertão do Apodi-Rio Grande do Norte (RN), and Alto Sertão-Sergipe (SE).
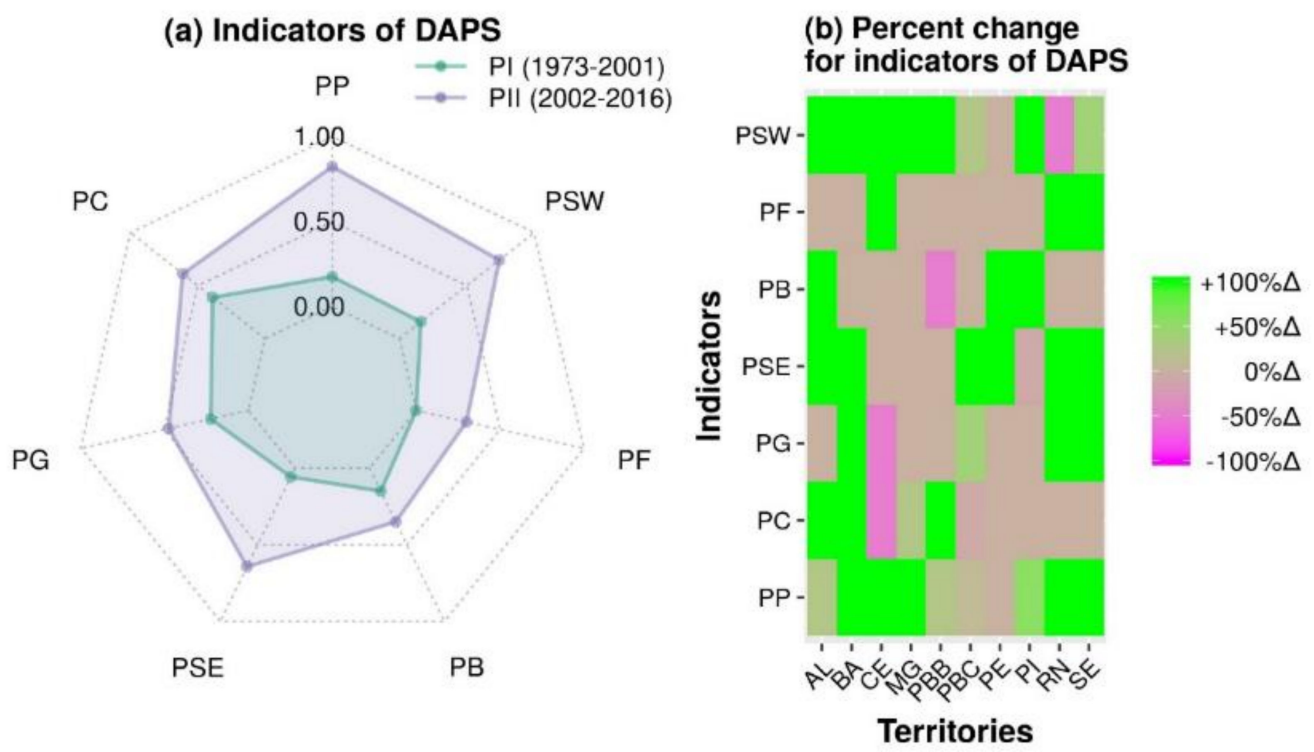

Figure 5. (a) Mean scores in PI (1973-2001) and PII (2002-2016) of the indicators comprising the macro-indicator Diversity of Animal Production Systems (DAPS): Production of Poultry (PP), Production of Cattle (PC), Production of Goats (PG), Production of Sheep (PSE), Production of Bees (PB), Production of Fish (PF), and Production of Swine (PSW); (b) Percent change in these same indicators from PI to PII by territory: Médio Sertão-Alagoa (AL), Sertão San Francisco-Bahia (BA), Ibiapaba-Ceará (CE), Alto Rio Pardo-Minas Gerais (MG), Borborema-Paraíba (PPB), Carirí-Paraíba (PBC), Sertão do Araripe-Pernambuco (PE), Vale do Guaribas-Piauí (PI), Sertão do Apodi-Rio Grande do Norte (RN), and Alto Sertão-Sergipe (SE). 
(a) Indicators of DCS

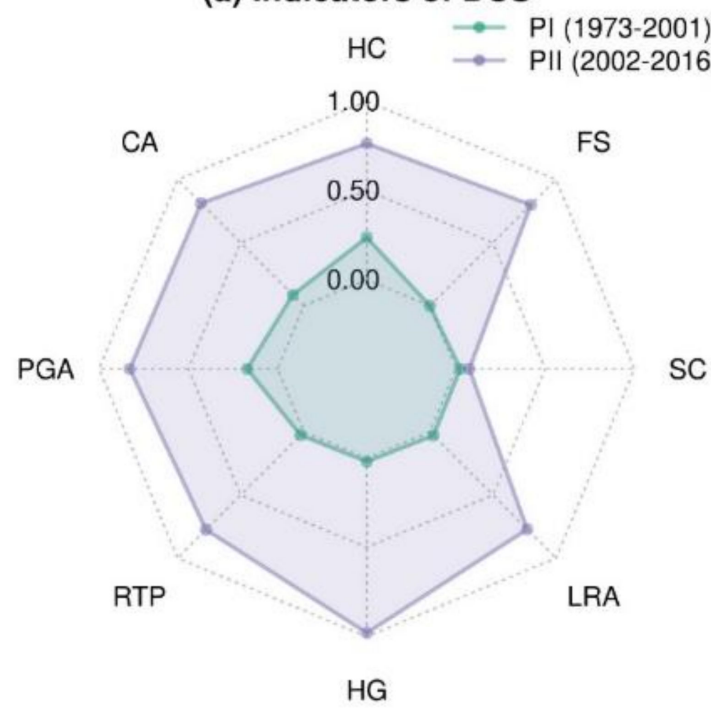

(b) Percent change for indicators of DCS

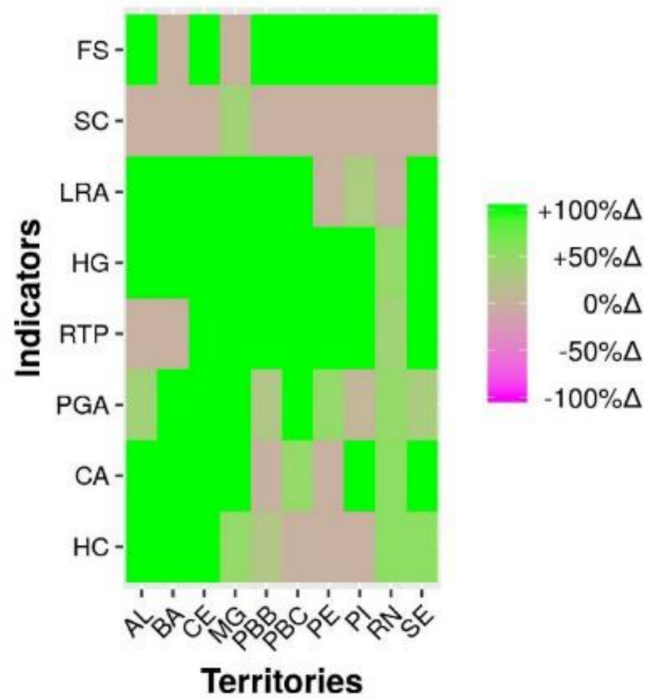

Figure 6. (a) Mean scores in PI (1973-2001) and PII (2002-2016) of the indicators comprising the macro-indicator Diversity of Cropping Systems (DCS): Horticultural Crops (HC), Crop Associations (Roçados, CA), Pastures and Grazing Areas (PGA), Reforestation and Tree Planting (RTP), Home Gardens (HG), Legal Reserve Areas (LRA), Shade-grown Coffee (SC), Forage Stocks (FS); (b) Percent change in these same indicators from PI to PII by territory: Médio Sertão-Alagoa (AL), Sertão San Francisco-Bahia (BA), Ibiapaba-Ceará (CE), Alto Rio Pardo-Minas Gerais (MG), Borborema-Paraíba (PPB), Carirí-Paraíba (PBC), Sertão do Araripe-Pernambuco (PE), Vale do Guaribas-Piauí (PI), Sertão do Apodi-Rio Grande do Norte (RN), and Alto Sertão-Sergipe (SE).

With respect to the indicators related to territorial governance, indicators related to Participation in the Management of Common Pool Resources (PMCPR)-including Family Seed Reserves (FSR), Community Seed Banks (CSB), Rotating Solidarity Funds (RSF), and collective Fruit Processingexperienced an average positive change of $49 \%$ (Figure 7). In the same way, Involvement in Spaces of Political Organizing (ISPO) presented better performance in PII, with an average positive change of $28 \%$ (Figure 8), especially due to increased Diverse Networks (DN, $+55 \% \Delta)$, Participation in Cooperatives $($ ASC, $+39 \% \Delta$ ), and Participation in Social Movements (PSM, $+15 \% \Delta$ ).

There was also increased access by families to the benefits of Public Programs (APP, Figure 9), particularly to Farmers Markets (Mercados de Agricultura Familiar or Ferias Agroecológicas, FA, $+42 \% \Delta$ ), Food Purchasing Program (Programa Adquisición de Alimentos, FPP, $+30 \% \Delta$ ), the National School Food Program (Programa Nacional da Alimentação Escolar, FPP, $+30 \% \Delta$ ), the Program for Family Farms (Programa da Agricultura Familiar, PFF, $+42 \% \Delta$ ), and Family Grants (Becas Familias, FG, $+10 \% \Delta$ ). 
(a) Indicators of PMCPR

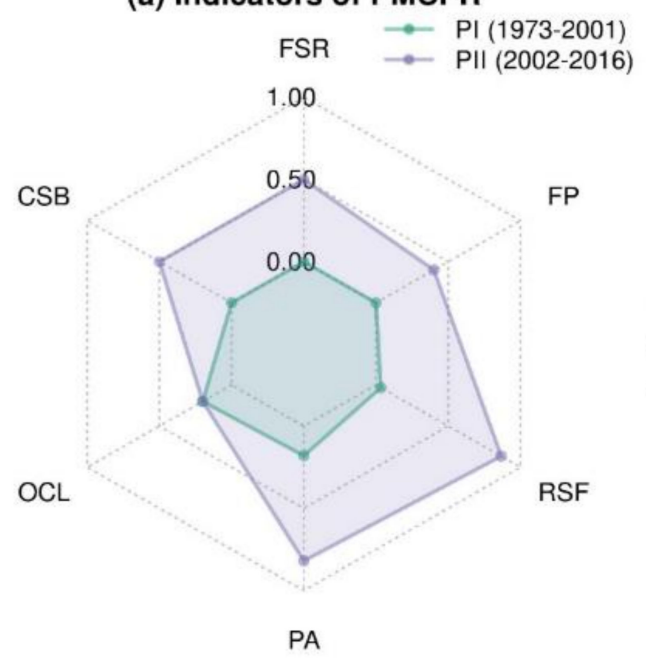

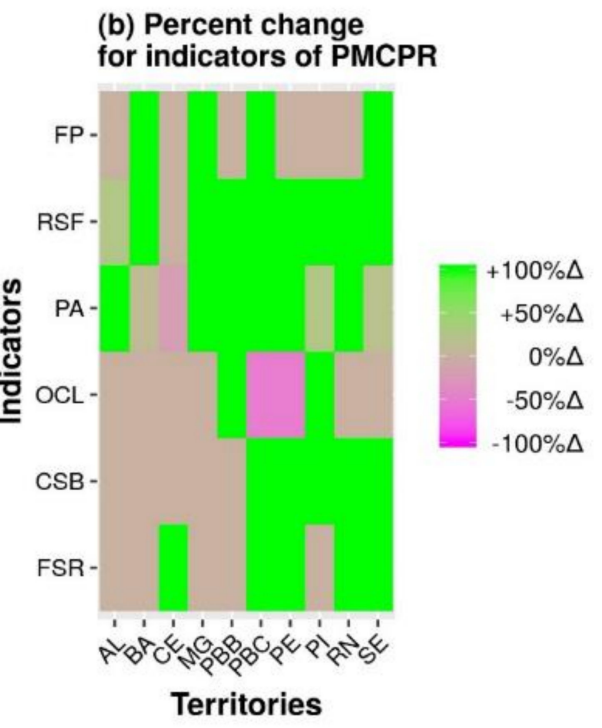

Figure 7. (a) Mean scores in PI (1973-2001) and PII (2002-2016) of the indicators comprising the macro-indicator Participation in the Management of Common Pool Resources (PMCPR): Family Seed Reserves (FSR), Community Seed Banks (CSB), Organization of Collective Labor (OCL), Participation in Associations (PA), Rotating Solidarity Funds (RSF), Fruit Processing (FP); (b) Percent change in these same indicators from PI to PII by territory: Médio Sertão-Alagoa (AL), Sertão San Francisco-Bahia (BA), Ibiapaba-Ceará (CE), Alto Rio Pardo—Minas Gerais (MG), Borborema-Paraíba (PPB), Carirí-Paraíba (PBC), Sertão do Araripe-Pernambuco (PE), Vale do Guaribas-Piauí (PI), Sertão do Apodi-Rio Grande do Norte (RN), and Alto Sertão-Sergipe (SE).
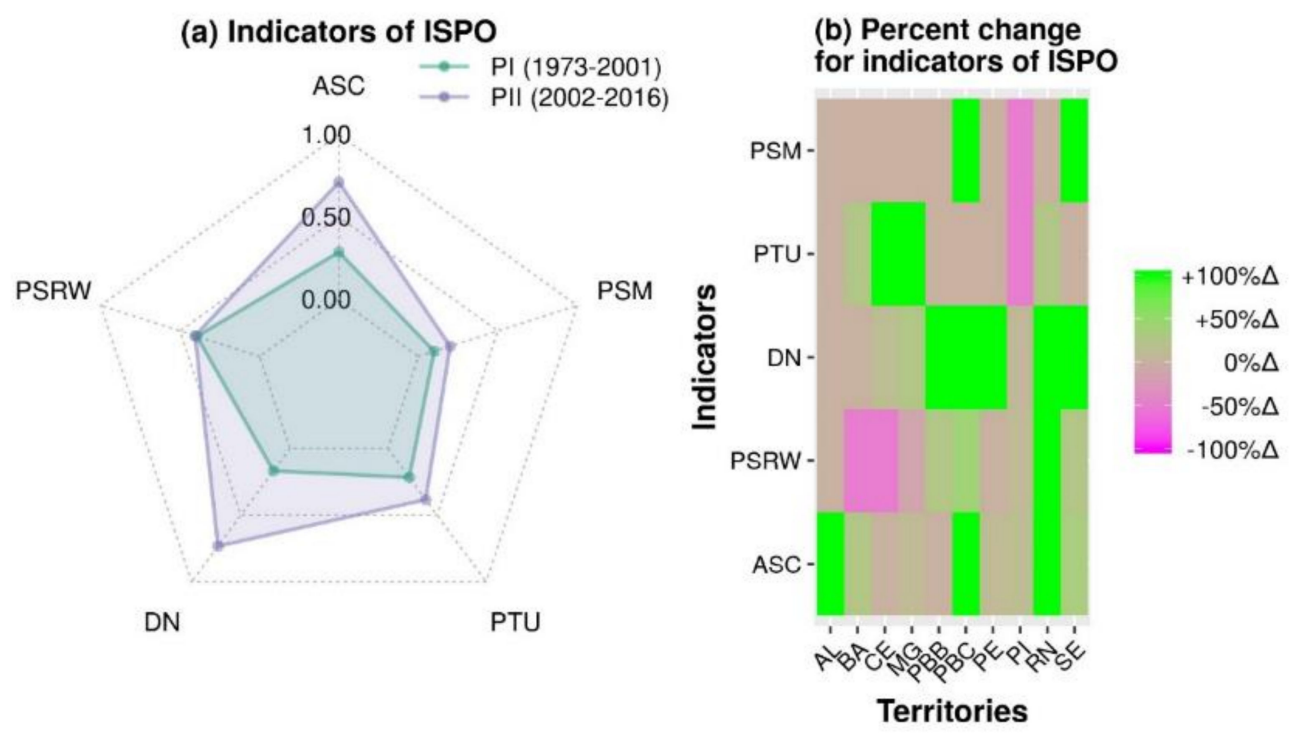

Figure 8. (a) Mean scores in PI (1973-2001) and PII (2002-2016) of the indicators comprising the macro-indicator Involvement in Spaces of Political Organizing (ISPO): Participation in Associations and Cooperatives (ASC), Participation in Syndicates for Rural Workers (PSRW), Diverse Networks (DN), Participation in Trade Unions (PTU), Participation in Social Movements (PSM); (b) Percent change in these same indicators from PI to PII by territory: Médio Sertão-Alagoa (AL), Sertão San Francisco-Bahia (BA), Ibiapaba-Ceará (CE), Alto Rio Pardo-Minas Gerais (MG), Borborema—Paraíba (PPB), Carirí-Paraíba (PBC), Sertão do Araripe-Pernambuco (PE), Vale do Guaribas-Piauí (PI), Sertão do Apodi-Rio Grande do Norte (RN), and Alto Sertão-Sergipe (SE). 
(a) Indicators of APP

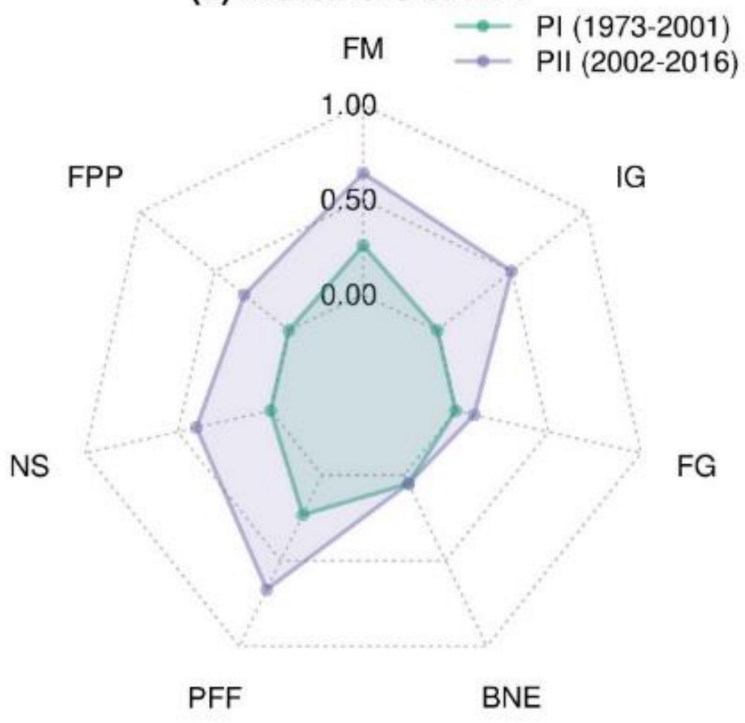

(b) Percent change

\section{for indicators of APP}

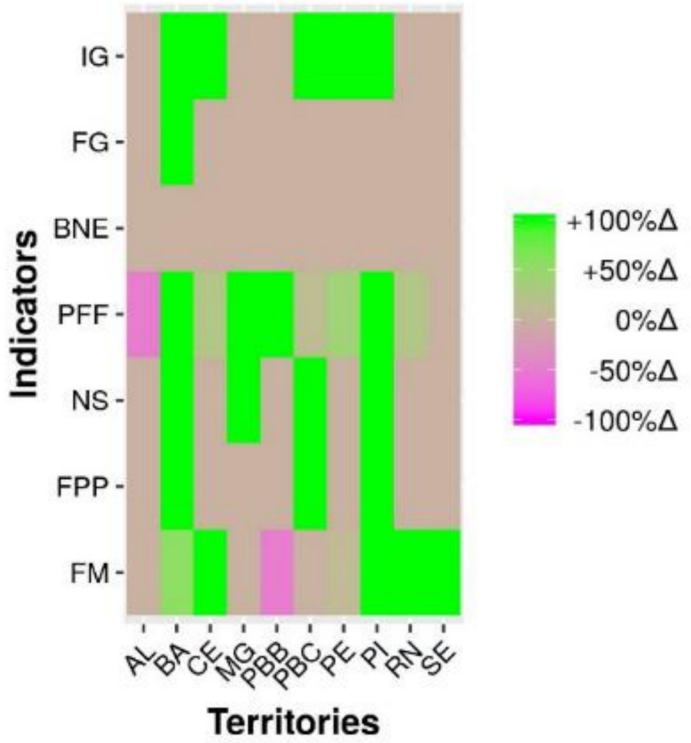

Figure 9. (a) Mean scores in PI (1973-2001) and PII (2002-2016) of the indicators comprising the macro-indicator Access to Public Programs (APP): Farmers Markets (FM); Food Purchasing Program (FPP); National School Food Program (Programa Nacional da Alimentação Escolar, NSFP), Program for Family Farms (Programa da Agricultura Familiar, PFF), Bank of the Northeast (Banco do Nordeste, BNE), Family Grants (Becas Familia, FG), Income from Grants (IG); (b) Percent change in these same indicators from PI to PII by territory: Médio Sertão-Alagoa (AL), Sertão San Francisco-Bahia (BA), Ibiapaba-Ceará (CE), Alto Rio Pardo-Minas Gerais (MG), Borborema-Paraíba (PPB), Carirí-Paraíba (PBC), Sertão do Araripe-Pernambuco (PE), Vale do Guaribas-Piauí (PI), Sertão do Apodi-Rio Grande do Norte (RN), and Alto Sertão-Sergipe (SE).

\section{Discussion}

The territories that we studied underwent substantial changes in PII related to technical innovations (i.e., domestic and production cisterns, crop associations, etc.) and social innovations (i.e., organization, participation, and public programs). The family farms in the 10 territories of SAB that we studied have promoted processes of improved production based on the valorization of local resources, the use of appropriate technologies, and agroecological management practices when combined with increased resource reserves-produce a greater circulation of resources within agroecosystems (Figures 2-9).

Similar results have been described in different studies realized in other territories of the SAB [21-24], as well as in other countries of Latin America, Asia, and Africa [1,5,25,26]. In China, we highlight the "Rice-Fish-Duck Systems" [27,28], in Latin America, the polyculture systems known as "Milpas" $[1,29,30]$. In these traditional systems, the increase in productivity per unit of land can vary between $20 \%$ and $60 \%$ in relation to other sole cropping or monoculture systems under the same management conditions [1,29,31]. In Ethiopia, the system developed for cultivating enset (Ensete ventricosum) provides various foods, as well as medicinal plants, forage, and fuel for domestic use. The associated animal raising - cattle, sheep, goats, horses, and donkeys-provides an additional source of protein and satisfies a high demand for manure that is used to fertilize the fields of enset $[5,29]$. In the Sahel, farmers have learned that associations between trees and crops known as agroforestry generate a series of benefits. The shade of trees offers protection to crops against harmful heat and winds, and increases the productivity from closely associated crops. At the same time, reforestation enhances important ecosystem functioning, such as the protection of water sources, 
the conservation of biodiversity, and the dispersal of seeds by birds and bats [5]. These studies suggest that traditional strategies for the management of natural resources in drylands are fundamentally sustainable, even though they are repeatedly negatively affected by government policies $[1,5]$.

In the particular case of the SAB's unstable water access, studies show that appropriate social technologies for the storage of rainwater (Table 1) lead to the adoption of initiatives that optimize the production of foods, that strengthen social organization, and that encourage the exchange of knowledge and innovative social practices [24]. Based on the local knowledge of social and productive technologies, the conditions are created to live in a sustainable way with semi-arid conditions, with the support of public policy. This of course requires the active participation and capacity to invent, reinvent, and propose new approaches that are incorporated in processes of organization and cooperation between organizations and social movements [32]. Regarding these processes, the concept of coexistence in the SAB has come to be understood based on its potential, the culture, the knowledge, and the capacity of people and social actors to create and recreate social processes that generate autonomy and empowerment [32]. This understanding provides visibility and coherence through the implementation of public policies that respond to the challenges faced by people.

Based on the accumulated experience of over four years of participatory research in the ten territories studied, and with the intention to better explain technical and social innovations (Tables 1 and 2, respectively) that represent a coexistence with semi-aridity comprised of agroecological strategies, we group the indicators identified in this study into three categories: (a) forming reserves of resources, especially water, nutrients, and energy; (b) reducing losses and increasing the efficient use of resources from family farms, such as soil, water, and organic matter; and (c) partnerships, organization, and synergetic relationships between diverse actors.

\subsection{Forming Reserves of Resources for Use during Periods of Drought}

Three strategies to highlight are (a) the capture of rainwater, (b) the implementation of local seed banks, and (c) the implementation of forage reserves. Technological innovations for rainwater capture include the Domestic Cisterns (DC) and Production Cisterns (PC) with storage capacities of 16 thousand liters and of 52 thousand liters, respectively. The primary capture of rainwater for DC is from the roofs of homes, and the water is used to drink and cook. This technology provides eight months of water for a family of five people. The second innovation, $\mathrm{CP}$, captures water on a paved surface of $200 \mathrm{~m}^{2}$ constructed directly on the soil. This paved area can capture $300 \mathrm{~mm}$ of rainfall and is sufficient to fill a cistern of 52 thousand liters that is lined with cement and built partly underground. Following the Map of Technologies of ASA-Brasil (2017), thus far there have been 595,524 Domestic Cisterns and 94,905 Production Cisterns built. These innovations have positively affected the economy of families, as was demonstrated by an economic analysis in Cariri, Paraíba [33]. The analysis compared the economy of families before and after accessing the water infrastructure. It was verified that with the presence of DC and PC, families obtained respectively 3.3 and 9 times greater profitability than without the technologies in terms of gross and agricultural profitability [33]. These systems for the better use of rainwater, for decades, have been used intensively in many arid and semi-arid regions of Africa, Asia, Europe, the Americas, and Oceania [34,35].

Another innovation is the creation of Family Seed Reserves (FSR) and Community Seed Banks (CSB), which make important contributions toward the food sovereignty of residents in the SAB [34,36,37]. Currently, 640 seed banks have been built in the region. Finally, we highlight the stocking of forage to feed animals in periods of drought. The most common technologies are to make hay and silage of native plants and crop residues, as well as living stocks of cacti such as Opuntia ficus-indica and Napolea cochenillifera (common name: Nopal Forrajero), Policereus gounelli (common name: Xique-Xique), and Cereus jamacaru (common name: Mandacarú). 


\subsection{Reducing Losses and Increasing Efficiencies on Family Farms}

Based on the variability and intensity of rains in the region of $\mathrm{SAB}$, the agroecosystems operate in accordance with the patterns of resource availability, and are greatly moderated by the availability of water $[12,38]$. Under these conditions, the innovations implemented by families are aimed to reduce losses of natural resources-water, soil, and nutrients-while increasing their usage efficiency based on strategies of (a) reforestation and biological diversification of agroecosystems with animal and crop species capable of more rapidly mobilizing spikes in resource availability while also introducing soil conservation practices (contour ditches, stone barriers, and organic soil amendments), and (b) management of native vegetation where it has not been removed totally and remains within and surrounding the farms.

Reforestation and diversification of agroecosystems buffer them from the negative effects of high climatic variability and simultaneously increase the production of biomass by more than $70 \%[39,40]$. These technological innovations produce excellent protein reserves and thus promote a greater stability in the production of biomass for animal consumption. Moreover, the production of biomass, reforestation, and diversification of agroecosystems of the SAB enable the harvesting of firewood, an important energetic source that meets the domestic needs of local families, representing $33 \%$ of the energetic supply in the region [41,42]. Similarly, posts and branches are used to construct fences and wooden barriers perpendicular to the slope to protect soils [43]. These practices often are complemented by soil conservation management techniques-small diffusion and infiltration canals, terraces, stone barriers, and living barriers of cacti-that regulate water flows and increase water infiltration [21]. Investigations indicate a reduction of $80 \%$ in the loss of soil by erosion [43-45] and increases of $25-150 \%$ in levels of soil organic matter in soils [39,46-48]. The living barriers of prickly pear cactus (Opuntia sp.) are capable of retaining up to $100 \mathrm{tha}^{-1}$ of soil per year [46].

There exists the potential for the sustainable management of native vegetation and forest resources where native vegetation still exists. These practices basically consist of removing non-forage vegetation and managing those species with the greatest forage potential through pruning and thinning. This increases the availability and productivity of forage without causing significant impacts on native biodiversity or on soils.

Another strategy for the management of native vegetation that applies specifically to the state of Bahía is called Forage Stocks (Fundos de Pastos) or Communities of Pasture Stocks (Comunidades de Fundos de Pastagens). In these systems, animals pasture in a collective area of native vegetation that can reach up to 3000 ha, which also allows the harvest of native fruits that are processed in micro-enterprises. For example, we reference the case study of Forage Stocks in Areia Grande, Bahía, an area where 365 families reside and work in a communal management of 27 thousand hectares of native vegetation (Caatinga) with very few individualized agricultural or animal production activities. During the dry periods, they obtain 30 tons of honey. Goats and sheep produce meat, milk, cheese, and hides without economic losses during the entire dry period. It is a system with elevated levels of autonomy, flexibility, and resilience to the climatic variability of the region as well as in terms of commercial relationships and dependence on external actors. Similar experiences have been described in other regions of the world [1,3-6,26].

These are the strategies that now provide the conditions for goats, sheep, fowl, pigs, cattle, and herbaceous and arboreal plants to share space within family farms of the SAB. They create different subsystems that provide food security and generate economic resources with the sale of surplus production in farmers' markets and to national food purchasing programs.

\subsection{Partnerships, Organization, and Synergy between Diverse Actors}

A reflexive and collaborative intervention increases solidarity over time in the shape of networks, associations, cooperatives, and social movements with the possibility to imagine and implement new public policies that enhance democratic access to water for the consumption of animals, crops, and humans [37]. Training in the collective management of resources reinforces strategies of coexistence 
with semi-aridity. Thanks to these engagements, technical and social innovations are communicated and discussed in all territories of the $\mathrm{SAB}$, following open processes of learning, co-education, questioning, consensus building, and the formulation of proposals and questions.

Processes of articulation, organization, and communication strengthened the autonomy and self-confidence of families, providing conditions to create, experiment, and replicate technologies [37]. In this way, these families spread processes of investigation and popular education. The exchange and co-construction of knowledge through participatory engagements result in multiple opportunities for synergy between actors, such as exchanges between communities, as well as municipal and provincial gatherings that now reach the national level in the National Meeting of Farmer Researchers (Encontro Nacional de Agricultores Investigadores, ENCONASA).

"Synergy" refers to a qualitatively greater advancement of ideas that occurs through the discussions at these meetings than the sum of what every participant could achieve on their own. For meetings to be synergetic, it is necessary to provide the necessary conditions through activities-in addition to focusing on technical knowledge - that stimulate the formation of friendship and solidarity based on a sense of mutual understanding that it is possible to build a more humanistic world.

The experiences of each family are synthesized in a magazine known as Candilero. At the moment of writing this article, 1269 experiences have been published and 48,250 exchanges between farmers have occurred. These processes awaken a collective strength, developing in the participants the power to advocate and demand steps toward the construction of public programs relevant to the region.

No doubt there is much more to do. According to the National Brazilian Institute for Geography and Statistics [20], social indicators are well below national and regional averages, and the majority of the SAB has experienced a slow growth due to a lack of basic infrastructure. Approximately $60 \%$ of the municipalities in the region have a human development index that varies between very low $(0.5)$ and low (0.6), which is less than the national human development index (0.72). The per capita gross domestic product is less than $60 \%$ of the national average. Illiteracy oscillates between $36 \%$ and $46 \%$, in approximately $46 \%$ of the municipalities.

\section{Conclusions}

The period from 2002-2016 increased the capacity of residents to mobilize the resources needed for technical and social reproduction in the 10 territories analyzed due to exchanges with nature-through the process of labor-and due to exchanges regulated by the communities (relations of reciprocity, organization, etc.). In this particular case study, and based on our experience during the entire process of investigation, we wish to highlight that coexistence went from a concept to action as a consequence of structural transformations of society and management practices in combination with a strengthening of mechanisms for communal reciprocity. This involves a coexistence characterized by (a) social mobilization and the establishment of channels to store resources for use during periods of drought, (b) the reduction of lost resources from agroecosystems and the efficient use of available resources, and (c) partnerships, organization, and synergetic moments for communicating between diverse actors.

This holistic vision affirms that coexistence with semi-aridity in SAB was made possible by public programs that permit (a) the democratization and access to soil, biodiversity, and water, (b) agroecology as a science and process practiced in communities that revitalizes small properties, and (c) contextualized education. In the years that follow, it will be necessary to amplify and consolidate this development initiative for the SAB with the effective inclusion of different sectors of local inhabitants in the region, especially those who had been overlooked by government policies in other times. For the characteristics of climate and physiography of the SAB, interventions in the region should maximize socioeconomic benefits for the current generation while conserving the quality of the environment and the capacity of production for future generations. There are many possibilities for the SAB: native fruits, flowers, ornamental plants, fragrances, minerals, artisan crafts, food, and a large assortment of wealth derived from phytotherapeutics across the region, and all this without speaking of ecological services or the fields of art and science. The semi-arid region continues to be a major 
challenge for Brazil, both in regard to its uniqueness and diversity as well as its territorial reach and high populations, which requires a greater commitment from governments and Brazilian society as a whole.

Acknowledgments: We wish to thank the National Institute of the Semi-Arid (INSA-MCTI), the Partnership for the Brazilian Semi-Arid Region (ASA-BRASIL), and Financier of Studies and Projects (FINEP) for financial support (agreement \# 01.13.0345.00), as well as the technical teams for assistance in field activities. We wish to thank the Laboratory of Agroecology at the University of California, Berkeley, United States for collaborating in the writing of this manuscript.

Author Contributions: Aldrin M. Pérez-Marin, Luis F. Ulloa, Luciano Silveira, and Victor M. Oliveira conceived, designed, and performed the research. Aldrin M. Pérez-Marin, Paul Rogé, and Barbara E. Domingues-Leiva analyzed the data. Aldrin M. Pérez-Marin, Paul Rogé, Luis F. Ulloa Forero, Miguel A. Altieri, Luciano Silveira, Vitor M. Oliveira, and Barbara E. Domingues-Leiva wrote the paper.

Conflicts of Interest: The authors declare no conflict of interest.

\section{References}

1. United Nations Environment Programme (UNEP). World Atlas of Desertification, 2nd ed.; Middleton, N., Thomas, D., Eds.; UNEP: London, UK, 1997; p. 182.

2. Altieri, M.A.; Nicholls, C.L.; Montalba, R. Technological Approaches to sustainable agriculture at a crossroads: An agroecological perspective. Sustainability 2017, 9, 349. [CrossRef]

3. Cooper, S.J.; Wheeler, T. Rural household vulnerability to climate risk in Uganda. Reg. Environ. Chang. 2017, 17, 649. [CrossRef]

4. Kattumuri, R.; Ravindranath, D.; Esteves, T. Local adaptation strategies in semi-arid regions: Study of two villages in Karnataka, India. Clim. Dev. 2017, 9, 36-49. [CrossRef]

5. Altieri, M.A.; Nicholls, C.L. The adaptation and mitigation potencial of traditional agricultura in a changing clamite. Clim. Chang. 2017, 140, 33-45. [CrossRef]

6. Davies, J.; Poulsen, L.; Schulte-Herbrüggen, B.; Mackinnon, K.; Crawhall, N.; Henwood, W.D.; Dudley, N.; Smith, J.; Gudka, M. Conservación de la Biodiversidad de las Tierras Áridas; IUCN: Gland, Switzerland, 2012; p. 84 .

7. White, R.P.; Nackoney, J. Drylands, People, and Ecosystem Goodsand Services: A Web-Based Geospatial Analysis; World Resources Institute: Washington, DC, USA, 2003; p. 58.

8. Medeiros, S.S.; Cavalcante, A.M.B.; Perez-Marin, A.M.; Tinoco, L.B.M.; Salcedo, I.H.; Pinto, T.F. Sinopse do Censo Demográfico para o Semiárido Brasileiro; Instituto Nacional do Semiárido: Campina Grande, Brasil, 2012; p. 103.

9. Lima, R.C.; Cavalcante, A.M.B.; Pérez-Marin, A.M. Desertificação e Mudanças Climáticas no Semiárido Brasileiro, 1st ed.; Instituto Nacional do Semiárido: Campina Grande, Brasil, 2011; p. 209.

10. Pérez-Marin, A.M.; Cavalcante, A.M.B.; Medeiros, S.S.; Tinoco, L.B.M.; Salcedo, I.H. Núcleos de desertificação no semiárido brasileiro: Ocorrência natural ou antrópica? Parcer. Estrateg. 2012, 17, 87-106.

11. Menezes, R.S.C.; Sampaio, E.V.S.B.; Giongo, V.; Pérez-Marin, A.M. Biogeochemical cycling in terrestrial ecosystems of the Caatinga Biome. Braz. J. Biol. 2012, 72, 643-653. [CrossRef] [PubMed]

12. Menezes, R.S.; Sampaio, E.V.; Pérez-Marin, A.M.; Giongo, V. Ciclos biogeoquímicos, biomas e sistemas hídricos. In Base Científica das Mudanças Climáticas, 1st ed.; Ambrizzi, T., Araújo, M., Silva Dias, P.L., Wainer, I., Artaxo, P., Marengo, J.A., Eds.; Painel Brasileiro de Mudanças Climáticas: Rio de Janeiro, Brasil, 2012; pp. 21-24.

13. Furtado, C. O Nordeste e a construção do Brasil. In Celso Furtado e o Desenvolvimento Regional; Alencar Junior, J.S., Ed.; BNB: Fortaleza, Brasil, 2005; pp. 209-236.

14. Silva, A.R.M. Entre o combate à seca e a convivência com o semiárido: Políticas públicas e transição paradigmática. REN 2007, 38, 467-485.

15. Duque, G. "Conviver com a seca": Contribuição da Articulação do Semi-Árido/ASA para o desenvolvimento sustentável. Rev. Desenvolv. Meio Ambiente 2008, 17, 133-140. [CrossRef]

16. Diniz, P.C.O. Ação Coletiva e Convivência com o Semi-Árido: A Experiência Da Articulação do Semi-Árido Paraibano. Dissertação Mestrado, Federal University of Paraíba, João Pessoa/Campina Grande, Paraíba, Brasil, 2002. 
17. Duque, G.J. O solo e Água no Polígono das Seca; BNB: Fortaleza, Brasil, 2004; p. 334.

18. ASPTA (Assessoria em Projetos de Agricultura Alternativa). Avaliacão Econômica-Ecologica de Agroecossistemas; Parte II; Procedimentos metodológicos: Rio de Janeiro, Brazil, 2015; p. 47.

19. R Development Core Team. R: A Language and Environment for Statistical Computing; R Foundation for Statistical Computing: Vienna, Austria, 2016.

20. Instituto Brasileiro de Geografia e Estatística (IBGE). Censo Agropecuário 2006 Brasil, Grandes Regiões e Unidades da Federação; IBGE: Curitiba, Brasil, 2006; p. 775.

21. Santos, A.P.; Cunha, A.R.B.; Denis, A.A.C.; Perez-Marin, A.M. Vivencias e Praticas Para Coabitação no Semiárido Brasileiro: Ensaios e Reflexões; Instituto Nacional do Semiárido (INSA): Campina Grande, Brasil, 2016; p. 206.

22. Conti, I.L.; Schroeder, E.O. Estratégias de Convivência com o Semiárido Brasileiro; Fundação de Apoio da Universidade Federal do Rio Grande do Sul-FAURGS/Instituto Brasileiro de Desenvolvimento e Sustentabilidade-IABS/Agência Espanhola de Cooperação Internacional para o Desenvolvimento-AECID/ Ministério do Desenvolvimento Social e Combate à Fome-MDS/Editora IABS: Brasília, Brasil, 2013; 208p.

23. Neves, R.S.; Medeiros, J.C.A.; Silveira, S.M.B.; Morais, C.M.M. Programa Um Milhão de Cisternas: Guardando água para semear vida e colher cidadania. Rev. Agric. Exp. Agroecol. 2010, 7, 7-11.

24. Petersen, P.; Silveira, L. Las políticas públicas y las luchas por la emancipación de la agricultura familiar: Reflexiones desde la región semiárida de Brasil. Rev. Agric. 2016, 15, 66-77.

25. IPES-Food. From Uniformity to Diversity: A Paradigm Shift from Industrial Agriculture to Diversified Agroecological Systems. International Panel of Experts on Sustainable Food Systems. Available online: www.ipes-food.org (accessed on 6 May 2017).

26. Altieri, M.A.; Nicholls, C.I.; Henao, A.; Lana, M.A. Agroecology and the design of climate change-resilient farming systems. Agron. Sustain. Dev. 2015, 35, 869-890. [CrossRef]

27. Zheng, Y.; Deng, G. Benefits analysis and comprehensive evaluation of rice-fish-duck symbiotic model. Chin. J. Eco-Agric. 1998, 6, 48-51.

28. Lu, J.; LI, X. Review of rice-fish-farming systems in China-One of the Globally Important Ingenious Agricultural Heritage Systems (GIAHS). Aquaculture 2006, 260, 106-113. [CrossRef]

29. Food and Agriculture Organization (FAO). Save and Grow: A Policymaker's Guide to the Sustainable Intensification of Smallholder Crop Production; FAO: Rome, Italy, 2011.

30. Francis, C.A. Multiple Cropping Systems; MacMillan: New York, NY, USA, 1986.

31. Koohafkan, P.; Altieri, M.A. Forgotten Agricultural Heritage: Reconnecting Food Systems and Sustainable Development; Earthscan Food and Agriculture Series; Routeledge: London, UK, 2016.

32. Malvezzi, R. Semi-Árido-Uma Visão Holística; Conselho Federal de Engenharia e Agronomia (CONFEA): Brasília, Brasil, 2007; p. 140.

33. ASA-BRASIL. Programa Uma Terra e Duas Águas (P1+2). Síntese dos Estudos de Caso do Território de Atuação do Coletivo Regional das Organizações da Agricultura Familiar do Cariri, Curimataú e Seridó Paraibanos; ASA-BRASIL: Recife, Brasil, 2016; p. 26.

34. United Nations Evironment Programme (UNEP). Rainwater Harvesting and Utilisation; International Environmental Technology Centre: Osaka, Japan, 2000; p. 16.

35. Rockstrom, J. Water resources management in smallholder farms in Eastern and Southern Africa: An overview. Phys. Chem. Earth 2000, 25, 275-283. [CrossRef]

36. Almeida, P.; Cordeiro, A. Sistema de Seguridade da Semente da Paixão: Estratégias Comunitárias de Conservação de Variedades Locais no Semi-Árido; ASPTA: Rio de Janeiro, Brazil, 2001; p. 120.

37. Almeida, P.; Tardin, J.M.; Petersen, P. Conservando biodiversidade em ecossistemas cultivados. In Seria Melhor Mandar Ladrilhar? Biodiversidade Como, Para Que, Porque; Bensusan, N., Ed.; Instituto Sócio Ambiental: Brasília, Brazil, 2002; pp. 140-151.

38. Sabourin, E.; Duque, G.; Diniz, P.C.O.; Oliveira, M.S.L.; Granchamp, L.F. Reconnaissance publique des acteurs collectifs de l'agriculture familiale au nordeste. Cah. Agric. 2005, 14, 111-115.

39. Menezes, R.S.C.; Garrido, M.S.; Pérez-Marin, A.M. Fertilidade dos Solos no Semi-Árido. In Proceedings of the Congresso Brasileiro de Ciência do Solo xxx, Recife, Brasil, 12-22 July 2005.

40. Perez-Marin, A.M.; Menezes, R.S.C.; Dias, E.M. Efeito da gliricídia sepium sobre nutrientes do solo, microclima e produtividade do milho em sistema agroflorestal no agreste paraibano. Rev. Bras. Ciênc. Solo 2006, 30, 555-564. [CrossRef] 
41. Martins, J.C.R.; Menezes, R.S.C.; Sampaio, E.V.S.B.; Nagai, M.A. Produtividade de biomassa em sistemas agroflorestais e tradicionais no cariri paraibano. Rev. Bras. Eng. Agríc. Ambient. 2013, 17, 581-587. [CrossRef]

42. Araújo Filho, J.A.; Carvalho, F.C. Sistemas de produção agrosilvopastoril para o Semi-Árido Nordestino. In Sistemas Agroflorestais Pecuários: Opções de Sustentabilidade Para Áreas Tropicais e Subtropicais; Carvalho, M.M., Alvim, J.M., Carneiro, J.C., Eds.; Embrapa Gado Leite: Juiz de Fora Brasília, Brazil, 2001; pp. 101-110.

43. Pérez-Marin, A.M.; Menezes, R.S.C.; Salcedo, I.H. Produtividade de milho solteiro ou em aléias de gliricídia adubado com duas fontes orgânicas. Pesqui. Agropecu. Bras. 2007, 42, 669-677. [CrossRef]

44. Pérez-Marin, A.M.; Vasconcelos, W.; Medeiros, S.S.; Tinoco, L.B.M.; Moreira, J.M.; Ulloa, L.F. Manual Metodológico: Práticas Mecânicas, Físicas e Biotecnológicas de Manejo Recuperação de Áreas Degradadas em Condições Semiáridas, 1st ed.; Instituto Nacional do Semiárido: Campina Grande, Brasil, 2015; p. 57.

45. Sampaio, E.V.S.B.; Salcedo, I.H.; Silva, F.B.R. Soil fertility in the semi-arid Northeast. In Annals Basic Input for Agriculture and Fight against Hunger, Proceedings of the 21st Brazilian Meeting on Soil Fertility and Plant Nutrition, Petrolina, Brazil, 16-20 October 1995; Embrapa-CPTSA/SBCS: Petrolina, Brazil, 1995; pp. 51-71.

46. Galindo, I.C.L.; Sampaio, E.V.S.B.; Menezes, R.S.C. Uso da palma na conservação dos solos. In A Palma No Nordeste Do Brasil: Conhecimento Atual e Novas Perspectivas de Uso; Menezes, R.S.C., Simões, D.A., Sampaio, E.V.S.B., Eds.; Universitária da UFPE: Recife, Brasil, 2005; pp. 163-176.

47. Menezes, R.S.C.; Salcedo, I.H.; Elliott, E.T. Microclimate and nutrient dynamics in a silvopastoral system of semiarid northeastern Brazil. Agrofor. Syst. 2002, 56, 27-38. [CrossRef]

48. Tiessen, H.; Menezes, R.S.C.; Salcedo, I.H.; Wick, B. Organic matter transformations and soil fertility in a treed pasture in semi-arid NE Brazil. Plant Soil 2003, 252, 195-205. [CrossRef]

(C) 2017 by the authors. Licensee MDPI, Basel, Switzerland. This article is an open access article distributed under the terms and conditions of the Creative Commons Attribution (CC BY) license (http:/ / creativecommons.org/licenses/by/4.0/). 